\title{
The Health and Well-Being Impacts of Protected Areas in Finland
}

\section{Puhakka, Riikka}

2017-11-09

Puhakka , R , Pitkänen , K \& Siikamäki , P 2017 , ' The Health and Well-Being Impacts of Protected Areas in Finland ', Journal of Sustainable Tourism , vol. 25 , no. 12 , pp. 1830-1847 . https://doi.org/10.1080/09669582.2016.1243696

http://hdl.handle.net/10138/307309

https://doi.org/10.1080/09669582.2016.1243696

acceptedVersion

Downloaded from Helda, University of Helsinki institutional repository.

This is an electronic reprint of the original article.

This reprint may differ from the original in pagination and typographic detail.

Please cite the original version. 


\section{Journal of Sustainable Tourism}

\section{The Health and Well-Being Impacts of Protected Areas in Finland}

\begin{tabular}{|c|c|}
\hline Journal: & Journal of Sustainable Tourism \\
\hline Manuscript ID & JOST-3312.R2 \\
\hline Manuscript Type: & Special Issue Paper \\
\hline Keywords: & Nature-based tourism, Protected areas, National parks, Health, Well-being \\
\hline Abstract: & $\begin{array}{l}\text { Following the growth of nature-based tourism, national parks and other } \\
\text { protected areas have become important tourist attractions and tools for } \\
\text { regional development. Meanwhile, research on the impact of nature on } \\
\text { human health and well-being is increasing and taken into account in park } \\
\text { management. This study examines health and well-being benefits } \\
\text { perceived by visitors to Finland's protected areas. It is based on survey } \\
\text { data from five national parks and one strict nature reserve in } 2013-2015 \text { : } \\
\text { an on-site visitor survey }(\mathrm{N}=3152) \text { and an internet-based health and well- } \\
\text { being survey ( } \mathrm{N}=1 \text { 054). The study indicates that visitors' perceived } \\
\text { benefits to their well-being were highly positive. Visits to protected areas } \\
\text { promoted psychological, physical, and social benefits. In particular, park } \\
\text { visits were found to provide strong and multi-faceted, long lasting, } \\
\text { embodied and sensory well-being experiences as well as escape from } \\
\text { everyday life and work. Overnight visitors reported more well-being } \\
\text { benefits than day visitors, and different types of park had different well- } \\
\text { being benefits. The study suggests that the potential benefits of protected } \\
\text { areas for public health are significant, emphasizing the need to integrate } \\
\text { health and well-being arguments into the neoliberalist politics assessing } \\
\text { the economic benefits of protected areas and their role in regional } \\
\text { development. }\end{array}$ \\
\hline
\end{tabular}


JOST3312FR

\title{
The Health and Well-Being Impacts of Protected Areas in Finland
}

\begin{abstract}
Following the growth of nature-based tourism, national parks and other protected areas have become important tourist attractions and tools for regional development. Meanwhile, research on the impact of nature on human health and well-being is increasing and taken into account in park management. This study examines health and well-being benefits perceived by visitors to Finland's protected areas. It is based on survey data from five national parks and one strict nature reserve in 2013-2015: an on-site visitor survey $(\mathrm{N}=3$ 152) and an internetbased health and well-being survey $(\mathrm{N}=1054)$. The study indicates that visitors' perceived benefits to their well-being were highly positive. Visits to protected areas promoted psychological, physical, and social benefits. In particular, park visits were found to provide strong and multi-faceted, long lasting, embodied and sensory well-being experiences as well as escape from everyday life and work. Overnight visitors reported more well-being benefits than day visitors, and different types of park had different well-being benefits. The study suggests that the potential benefits of protected areas for public health are significant, emphasizing the need to integrate health and well-being arguments into the neoliberalist politics assessing the economic benefits of protected areas and their role in regional development.
\end{abstract}

Keywords: nature-based tourism, protected areas, national parks, health, well-being, Finland 


\section{Introduction}

Following the growth of nature-based tourism, national parks and other protected areas have become important tourist attractions and tools for regional development. According to recent modeling, protected areas are globally visited c. 8 billion times annually: $80 \%$ of those visits are in Europe and North America (Balmford et al., 2015). Visitor numbers in protected areas have also increased in northern Europe, including Finland (Puhakka \& Saarinen, 2013). In particular, the national park label has been shown to increase the attractiveness of protected areas (Wall Reinius \& Fredman, 2007). Therefore, the global tourism industry has become a significant user, stakeholder, and element of change in protected areas. Coordinating conservation and the utilization of nature is often considered advantageous for both conservation and regional development goals. The touristic attractiveness of natural areas is seen as offering potential income for local peripheral communities struggling with economic restructuring (Hammer, Mose, Siegrist, \& Weixlbaumer, 2007; cf. Byström \& Müller, 2014; Mayer, 2014). Thus, protected areas increasingly justify their existence by local and regional economic gain and by satisfying visitor need. This discursive policy shift reflects the rise of neoliberalist politics in which nature conservation has become more instrumental and market oriented than before (Puhakka \& Saarinen, 2013). These developments have important and far reaching management implications.

Although recreation has been an integral part of national parks since the beginning, interest in the potential role of parks in human health and well-being is relatively new. Meanwhile, there are growing efforts to develop nature-based well-being tourism (e.g. Hjalager et al., 2011). Empirical evidence is mounting that contact with nature promotes mental and physical health. Direct physical and emotional health benefits arise from the opportunity to observe nature and be in a natural environment (Maller et al., 2008). Natural settings activate people to move, which produces indirect health benefits (Björk et al., 2008). Nature also promotes people's mutual interaction and their sense of community (Health Council..., 2004). It has been argued that current health care practices alone cannot deal with the growing stress and other problems connected with urban living and contemporary work practices (Karjalainen, Sarjala, \& Raitio, 2010). The economic implications of the benefits of natural environments to health and well-being have been considered substantial. Utilizing green spaces effectively 
in health promotion could reduce public health care budgets and create new sources of income (see Nilsson, Baines, \& Konijnendijk, 2007).

National parks and other nature reserves with recreational value can thus be seen as a fundamental health resource, particularly in terms of disease and illness prevention (Maller et al., 2008; Stolton \& Dudley, 2010). While research on the health and well-being benefits of nature has a long history, previous studies have focused on the effects on physical health, psychological well-being, and cognitive ability (Keniger, Gaston, Irvine, \& Fuller, 2013). And, research has largely focused on urban and suburban parks while the perceived health benefits of visitors to national parks and nature reserves have not been widely studied (see Bowler, Buyung-Ali, Knight, \& Pullin, 2010). Also, most of the research has been carried out in North America (e.g. Lemieux, Eagles, Slocombe, Doherty, Elliott, \& Mock, 2012;

Lemieux et al., 2015), and comparisons between different kinds of protected areas have been rare (see Weber \& Anderson, 2010). Accordingly, more research on the perceived health and well-being outcomes associated with visiting different types of protected areas is needed.

This study examines the health and well-being benefits perceived by visitors to national parks (IUCN Category II) and strict nature reserves (IUCN Category IA) in Finland. First, the article analyses the type and strength of health and well-being benefits. Second, the article explores if different demographic characteristics or characteristics of a park visit lead to different perceived health and well-being outcomes. The study is based on two types of survey data collected in five national parks and one strict nature reserve: an on-site visitor survey $(\mathrm{N}=3$ 152) and an internet-based health and well-being survey $(\mathrm{N}=1054)$. Data was collected during years 2013-2015. The study aims to discuss the new and additional mandate of protected areas as 'the fountains of health and well-being' in urbanized societies.

\section{The Impact of Nature on Human Health and Well-Being}

\section{Psychological and Cognitive Benefits}


Previous studies on the psychological benefits of interacting with nature can broadly be divided into psychological well-being benefits and those associated with cognitive performance, i.e. positive effects on mental processes and cognitive ability or function (Keniger et al., 2013; see Bowler et al., 2010).

Interaction with nature has been shown to increase self-esteem and mood (Kuo \& Sullivan, 2001), reduce anger (Moore, Townsend, \& Oldroyd, 2007), and improve general psychological well-being with positive effects on emotions and behavior (Kaplan, 2001). The positive impacts of nature on children's self-esteem and mental well-being has also been discovered (Maller, 2009).

Several studies have focused on the psychological well-being effects of exercising in a natural environment (Keniger et al., 2013). The multi-study analysis by Barton and Pretty (2010) showed that acute short-term exposures to facilitated 'green exercise' improved both self-esteem and mood irrespective of duration, intensity, location, gender, age, and health status (see also Pretty, Peacock, Hine, Sellens, South \& Griffin, 2007). Considerable improvements in well-being, mood, relaxation, joy, and other health and well-being indicators were also perceived by hikers, runners and walkers in national parks (Wolf \& Wohlfart, 2014). Research suggests that exercise is more beneficial, leading to the relief of anxiety and depression, when it occurs in natural rather than urban settings (Hartig, Mang, \& Evans, 1991). A national study in Finland indicated that repeated exercise in nature was, in particular, connected to better emotional well-being (Pasanen, Tyrväinen, \& Korpela, 2014). A green environment is considered to encourage people to exercise more often and for longer periods than a non-natural environment which has positive benefits for both mental health and physical fitness (Health Council..., 2004; Kaczynski \& Henderson, 2007). Besides exercise, intentional interactions with nature, such as watching wildlife, have been shown to increase psychological well-being (Curtin, 2009).

In terms of cognitive benefits, it has been hypothesized that green spaces are restorative, contributing to attentional recovery and reducing mental fatigue (Björk et al., 2008; Hartig, Evans, Jamner, Davis, \& Gärling, 2003; Kaplan, 2001; Tyrväinen, Ojala, Korpela, Lanki, 
Tsunetsugu, \& Kagawa, 2014). In a Finnish study, Korpela, Borodulin, Neuvonen, Paronen, and Tyrväinen (2014) discovered that the longer the time in nature-based recreation associated with restorative experiences, the better emotional well-being is perceived. Many of the health and well-being benefits from outdoor activities can be ascribed to the restorative capacity of natural environments (Wolf, Stricker, \& Hagenloh, 2015). Research findings suggest that exposure to nature in urban and wilderness settings has positive effects on academic performance and the ability to perform mentally challenging tasks (Berman, Jonides, \& Kaplan, 2008). For instance, Hartig et al. (1991) concluded that a prolonged wilderness experience had restorative effects. Van den Berg, Koole and van der Wulp (2003) showed that, compared with urban environments, natural environments have positive impacts on the ability to concentrate. Performing activities in green areas has been found to reduce the symptoms of attention-deficit/hyperactivity disorder (AD/HD) in children (Kuo \& Taylor, 2004). In addition, positive, restorative experiences in natural environments may promote greater ecological behavior (Hartig, Kaiser, \& Strumse 2007).

According to Han (2010), natural environments differ in their restorative potential. Many studies have explored, for instance, the positive contribution of the forest environment on psychological health and well-being (see Karjalainen et al., 2010; Shin, Yeoun, Yoo, \& Shin, 2010). Barton and Pretty (2010) concluded that spending time near waterside (e.g. beach or river) or participating in water-based activities may give a greater benefit although all green environments improved their participants' self-esteem and mood. Fuller, Irvine, DevineWright, Warren and Gaston (2007), in turn, found that the restorative benefits to urban park users increased with plant species richness in urban green spaces.

\section{Physiological Benefits}

Research has identified a broad range of physiological benefits from interacting with nature, i.e. positive effects on physical function and/or physical health. Research findings suggest that contacts with green space alleviate the negative physiological effects of various stressors in urban environments (Lee, Li, Tyrväinen, Tsunetsugu, Park, Kagawa, \& Miyazaki, 2012; Tsunetsugu, Park, Ishii, Hirano, Kagawa \& Miyazaki, 2007). Compared with urban 
environments, natural environments produce positive changes in human physiology after stressful or attention-demanding situations (van den Berg et al., 2003; Hansmann, Hug, \& Seeland, 2007; Hartig et al., 2003). For instance, blood pressure, heart rate, skin conductivity, and muscle tension are at lower levels in natural environments than in urban settings. Forest visits also reduce salivary cortisol levels (stress hormone), suppress sympathetic nervous activity, and enhance para-sympathetic nervous activity (Hartig et al., 2003; Lee et al., 2012; Tyrväinen et al., 2014).

Natural settings activate people to move and, thus, increase energy expenditure and produce indirect physical health benefits. For instance, Björk et al. (2007) found that recreational values for nearby natural environments were positively associated with physical activity and also with a normal or low Body Mass Index (BMI) for tenants. Wolf and Wohlfart (2014) observed that although hiking in national parks was performed with the primary motivation to experience nature and not to exercise, hikers burned more energy than runners and walkers as they preferred more difficult tracks with greater slopes.

Visits to green areas may also strengthen the human immune system by increasing natural killer (NK) activity. NK cells can kill tumor cells by releasing anticancer proteins and, thus, nature visits may have a preventive effect on cancer generation and development (see Lee et al., 2012). Furthermore, interactions with the natural environment influence the composition of the human commensal microbiota and its immunomodulatory capacity. The "biodiversity hypothesis" proposes that reduced contact with natural environment and biodiversity, including environmental microbiota, leads to poor human microbiota, immune dysfunction and finally to chronic inflammatory diseases (Hanski et al., 2012).

\section{Social and Spiritual Benefits}

Nature can also have a beneficial effect on health by promoting social contact (Health Council..., 2004). Natural environments and shared nature experiences provide opportunity for social interaction and strengthen bonds within families and communities (Wolf et al., 
2015). Research suggests that provision and access to natural environments may ameliorate or even reverse some of the social challenges in urban areas (Keniger et al., 2013). Natural environments foster social empowerment, enhance interracial interaction, and promote social cohesion and support (e.g. Kuo \& Sullivan, 2001; Maller, 2009). Nature can help in personal and community identity formation, social activity, and social participation (Irvine \& Warber, 2002). In comparison with urban areas with limited greenery, significantly lower levels in crime rates and violent behavior have been observed in urban areas with surrounding green space or vegetation (Kuo \& Sullivan, 2001; Moore, Townsend \& Oldroyd, 2007).

A small number of studies have focused on the spiritual benefits of interacting with nature. Spiritual benefits identified include the increased inspiration and feelings of connectedness to a broader reality (e.g. Curtin, 2009; Fredrickson \& Anderson, 1999; Humberstone, 2011). Participation in rural tourism has also been found to elicit a deeper, emotional or spiritual experience (Jepson \& Sharpley, 2015).

\section{Study Areas}

Parks \& Wildlife Finland (formerly Natural Heritage Services) manages state-owned protected areas in Finland, including 39 national parks and 19 strict nature reserves. Parks \& Wildlife Finland is a unit of the state-owned enterprise Metsähallitus which runs business activities on state-owned land and water areas while also fulfilling public administration duties, such as nature conservation, facilities and services for outdoor recreation, and protected area management planning. While national parks are important destinations for recreation, strict nature reserves are primarily reserved for the purposes of nature conservation and research (see Metsähallitus, 2016a).

In 2010, Parks \& Wildlife Finland launched the Healthy Parks, Healthy People Finland program that aims to improve public health by activating people to get out into natural settings, enjoy positive and genuine experiences, and improve their physical health through 
outdoor activities. The key objective is to effectively monitor and measure the health benefits of protected areas so that the findings can be used to enhance services.

This study is based on survey data collected by Parks \& Wildlife Finland in six protected areas: Kurjenrahka, Patvinsuo, Repovesi, Pyhä-Luosto, and Syöte National Parks as well as Kevo Strict Nature Reserve. These areas were selected to represent parks located in different parts of Finland and with different geographical and visitor characteristics (see Figure 1, in Supplemental Data in the on line version of this paper). The results of Puustinen, Pouta, Neuvonen and Sievänen (2009) indicated that both the natural characteristics of national parks, recreation services and the tourism services in the surrounding municipalities were associated with the number of park visits in Finland (see Table 1). The number of visits is the highest in northern parks characterized by fells (i.e relatively mountainous formations) and abundant recreation and tourism services (e.g. Pyhä-Luosto), while in parks dominated by bog land or mires (e.g. Patvinsuo) the recreation service level has not affected the number of visits. Biodiversity has also been shown to be linked with the perceived attractiveness of Finnish national parks - parks with high biodiversity values are more attractive for visitors than parks with lower biodiversity values (Siikamäki, Kangas, Paasivaara, \& Schoderus, 2015).

[Figure 1 near here]

Kevo Strict Nature Reserve in the northernmost Finland was established in 1956 and extended in 1982. Kevo is the largest strict nature reserve in Finland with an area of over 712 $\mathrm{km}^{2}$. As Kevo is located in a sparsely populated area and far away from the major tourist centers of northern Finland, the number of yearly visits is only about 5000 (Table 1). Kevo is popular especially for long-distance wilderness hikes; the 40-km-long canyon-like valley of the River Kevojoki forms the core of the area. Inside the strict nature reserve visitors are allowed to walk only on marked trails.

[Table 1 near here] 
Pyhä-Luosto and Syöte National Parks are located near middle-sized skiing resorts in sparsely populated northern Finland. Pyhätunturi National Park was established in 1938, but the entire Pyhä-Luosto area, with an area of $142 \mathrm{~km}^{2}$, was designated as a national park in 2005. Pyhä-Luosto National Park combining two popular fell areas attracts both day trippers and long-distance hikers; the number of yearly visits is over 115000 (Table 1). Syöte National Park was established in 2000 and it covers an area of $299 \mathrm{~km}^{2}$. In Syöte, landscape changes from broad aapa mires ${ }^{i}$ to wilderness-like hills growing spruce forests. There are marked trails for day trips as well as for longer hikes. According to visitor studies, in PyhäLuosto, Syöte, and Kevo approximately $90 \%$ of the visitors stay overnight in the surrounding area or in the park and the share of local visitors is low.

Patvinsuo National Park, established in 1982, is located in sparsely populated eastern Finland, and it covers an area of $105 \mathrm{~km}^{2}$. There are both raised bogs and open aapa mires in the park. The park is suitable for one or two-day hikes and observing the natural environment of the wilderness. Patvinsuo is the least visited national park in this study, and over half of its visitors come from the surrounding area or nearby cities (Table 1).

Kurjenrahka and Repovesi National Parks are located in more densely populated southern Finland, and they are much smaller than the other study areas. Kurjenrahka National Park, 29 $\mathrm{km}^{2}$, was designated as a national park in 1998. Kurjenrahka includes the largest raised bogs of southwestern Finland, which are in their natural state. Within an easy access from the city of Turku with 186000 inhabitants, Kurjenrahka is the only close-to-home-recreation area in this study. Kurjenrahka is a destination for day trips but also for longer excursions. Repovesi National Park was established in 2003, and it covers an area of $15 \mathrm{~km}^{2}$. Rugged forests in Repovesi are dotted with lakes and ponds, and it is located within a two hour drive from the capital city Helsinki. Repovesi is one of the most popular hiking areas in southern Finland and suitable for both day trippers and overnight hikers. The number of yearly visits has grown fast to over 140000 (Metsähallitus, 2016b; see Table 1). 


\section{Materials and methods}

This study was inspired by the study of Lemieux et al. (2012) exploring the perceived health and well-being benefits of two protected areas in Canada. In their study, a questionnaire was developed to reflect a comprehensive suite of health and well-being indicators (or attributes): physical, psychological/emotional, social, intellectual, spiritual, ecological, environmental, cultural, occupational, and economic well-being. The perceived benefits received from protected area experiences were substantial; the greatest well-being benefits were psychological/emotional, social, cultural, and environmental.

In this study two types of survey data were used (Table 2). In the first phase, data was collected through an on-site visitor survey $(\mathrm{N}=3152)$. Visitor surveys are conducted by Parks $\&$ Wildlife Finland on state-owned conservation and recreational areas every five years. The survey questionnaire includes questions on the length of a visit, travelling to the destination, motives, activities, service demand and rating as well as spending of money. To find out about health and well-being benefits, the visitors were asked to what extent they thought that the visit increased their social, psychological and physical well-being respectively ( $1=$ strongly disagree ...5=strongly agree) and to estimate the monetary value of perceived well-being benefits. Social well-being was specified as "e.g., improved working capacity, strengthened social relations, enjoyed doing things alone or together," psychological wellbeing as "e.g., satisfaction with life, improved the mood, recovery from mental stress, learned something new", and physical well-being as "e.g., enjoyed sensing the nature, maintained the fitness, learned new skills, perceived physical well-being”. In addition, visitors were prompted to leave their email address to participate in the more detailed second survey.

[Table 2 near here]

In the second phase, those respondents who had left their contact details were emailed a web questionnaire approximately one week after their visit $(\mathrm{N}=1054)$. The web survey included 36 statements of different well-being effects assessed with a 5-point Likert-scale (1=strongly 
disagree...5=strongly agree). The statements covered different aspects of physical well-being benefits (activities, sensations), psychological well-being (restoration, relaxation, being creative, intellectual stimulation), and social well-being (interaction, togetherness, bonding, occupational well-being). The statements were designed based on the Canadian study (Lemieux et al., 2012) but adapted to the Finnish context. Questions related to economic, cultural, and ecological well-being were left out of the survey. In addition, the questionnaire included a structured question on the visitors' estimation on the duration of the positive impacts ("for a long time", "for some time", "during the visit", "no positive impacts"), the monetary valuation of the impacts (open-ended), respondents' relationship with the place of a visit (protected area), their physical exercise habits and physical characteristics, their relationship with nature, and if they travelled with children, the impacts of the visit to the children. The visitor survey was available in several languages, while the web survey was available only in Finnish (Kaikkonen, Virkkunen, Kajala, Erkkonen, Aarnio, \& Korpelainen, 2014). On average, the web survey was responded to three weeks after the on-site survey.

Key demographic characteristics of both studies are presented in Table 3. The share of respondents with higher education is larger in the web survey, which indicates that especially the educated respondents of the visitor survey left their contact details and answered the follow-up survey.

[Table 3 near here]

Data gathered through the questionnaires were combined, stored and analyzed using SPSS software. The results are reported in the following sections via the descriptive statistics of different variables. Differences between respondent groups are compared using the nonparametric Mann-Whitney U and Kruskall-Wallis tests since the data were not normally distributed.

Factor analysis was conducted to detect the different dimensions of well-being studied with the extensive web survey and to see how they compared with those of the Canadian study 
(Lemieux et al., 2012). Exploratory factor analysis via the principal component method and using Varimax-rotation (orthogonal) with Kaiser normalization resulted in 8 factors with eigenvalues greater than 1. Four variables that did not have a strong loading (below 0.5) at any of the factors were removed from the analysis after repeating the procedure twice. Two variables ("Weather conditions felt unpleasant", "I found insects (mosquitos, elk flies, wasps, mites etc.) disturbing”) were removed from the analysis as weather and insect conditions are highly changeable and dependent on the time of the visit. The remaining 30 variables had 6 factors with eigenvalues above 1 and explain together $59.5 \%$ of the variance. The factors were turned into composite variables by calculating an average of the variables assigned to each of the factor. These 6 variables were used as dependent variables in the analysis.

\section{Results of the on-site visitor survey \\ Type and strength of well-being benefits}

Visitors' perceived benefits to their health and well-being were highly positive. All three dimensions of well-being (social, physical, psychological) had means above 4 on the 5-point Likert-scale (Table 4). Physical and psychological well-being scored mean values above 4.4 and social well-being 4.2 .

[Table 4 near here]

As another indicator of the strength of the perceived well-being effects, the monetary value of the well-being benefits of the visit was surveyed in an open-ended question. As a reference, the respondents were given examples of prices of commercial wellness services ranging from a gym visit $(€ 5)$ to a trip abroad $(€ 3000)$. Responses ranged from 0 to $€ 100,000$, the median being $€ 150$. In the on-site survey $31.9 \%$ of respondents gave values under or equal to $€ 50$ and $16.1 \%$ between $51-€ 100$. Forty-two percent of respondents estimated the value to be in the range of $101-€ 500,1.6 \%$ between $501-€ 999$, and $8.4 \%$ above or equal to $€ 1000$. 
The impact of background variables on the perception of well-being benefits was studied comparing respondent groups of different gender, age, and education. The impact of the characteristics of the visit, in turn, was studied comparing visitors to different protected areas, day and overnight visitors, those who travelled alone vs. in a group, and first-time vs. repeat visitors (Table 4).

In general, women rated all well-being benefits higher than men. The oldest ( 65 and older) and the youngest (under 30) age group rated the three types of well-being benefits the lowest, while those between 30-64 years of age gave higher ratings. The youngest and the oldest differed significantly from others in terms of social and psychological well-being, while in terms of physical well-being only the difference between the youngest and middle age group (45-64 years old) was significant.

Differences between the visitor ratings of different areas were significant, especially in relation to social and physical well-being. The visitors to Kevo, Syöte, Pyhä-Luosto, and Patvinsuo in northern and eastern Finland rated higher the different forms of well-being benefits they had gained during the visit. In turn, Kurjenrahka and Repovesi visitors in more densely populated southern Finland gave the most moderate ratings.

In terms of length of stay, overnight visitors perceived the impacts more positively than those who stayed a shorter time. Especially psychological well-being was rated higher by overnight respondents. Travel companion affected people's perceptions so that those who travelled alone rated physical well-being higher than others, whereas those who had company rated social well-being higher than others. There were no significant differences between first-time and repeat visitors. 


\section{Results of the web survey}

Type and strength of well-being benefits

The six latent factors identified by factor analysis from the extensive web survey gave a more detailed understanding about the different dimensions of health and well-being benefits than the three dimensions used in the on-site survey (Table 5). The first factor includes variables related to restoration and relaxation ("My vitality and energy increased", "I calmed down", "My concentration improved") as well as self-esteem ("My self-confidence increased", "I got better hope for tomorrow", "My life was put into perspective"). These have often been listed as the key psychological well-being benefits of nature (Keniger et al., 2013) as well as protected areas (Lemieux et al., 2012). In this study, psychological well-being was associated with improved work motivation and motivation for everyday life that is occupational wellbeing as defined by Lemieux et al. (ibid). Therefore, the first factor was named as Psychological and occupational well-being.

[Table 5 near here]

Variables relating to cognitive skills and opportunities to engage in creative and stimulating activities (see Lemieux et al., 2012) were loaded into the second factor ("I learned new skills", "I learned more about nature", "My interest towards nature increased"), which was named as Intellectual well-being. Also the variable "I enjoyed meeting new people during the visit" had the highest loading to the second factor.

Related to psychological well-being, a separate third factor was formed by variables "I forgot everyday worries", "I had a chance to get away from work" and "I had a chance to get away from everyday life". These are all variables related to finding a counterbalance to stressful everyday life and work: this factor was named as Escape. 
The fourth factor was called Social well-being. It consists of variables promoting togetherness, social contact, participation, and bonding that have been found to be important social well-being benefits from nature ("I enjoyed spending time with people I cherish", "I enjoyed shared activities with people I cherish", "I found it easier to talk about personal matters in nature", "Being in nature fostered my relationship with people I cherish") (see Lemieux et al., 2012). In addition, the variable "Having company increased my feeling of security" loaded to the factor, which suggests that common experiences in somewhat challenging natural environments may strengthen bonds with family members and friends.

Variables related to the perceived benefit to Physical well-being were loaded to the fifth factor. These included variables related to exercise ("During my visit to the area I exercised more than in everyday life", "I felt the nature exercise improved my physical condition"), being able to test one's physical strength ("I was able to test my physical strength"), and in general the feeling of physical well-being ("I felt my physical well-being improved") (see Lemieux et al., 2012).

Separate from physical fitness, strength, and exercise, the sixth factor was formed by variables emphasizing the different sensations provided by the visit. These were related to sound ("I enjoyed sounds of nature", "I enjoyed silence"), sight ("I enjoyed beautiful nature"), smell ("I enjoyed the fragrance of nature", "It felt good to breathe fresh air"), and feel ("The feel of nature was pleasant (wind on my face, soft moss, the shapes of different surfaces"). These variables are related to the often instantaneous and momentary feelings provided by nature, and the factor was named as Sensory satisfaction.

Out of these six factors, Sensory satisfaction (factor 6) and Escape (factor 3) scored the highest mean values, above 4.5, while Intellectual well-being (factor 2) as well as Psychological and occupational well-being (factor 1) received the lowest ratings with mean values below 4 . The web survey thus deepens the result of the on-site visitor survey by 
suggesting that, in terms of physical well-being and psychological well-being, sensory satisfaction and escape from everyday life are especially important.

In line with the visitor survey, the web survey included a question on the monetary value of the perceived well-being benefits. The estimations of respondents on monetary value ranged from 0 euros to a billion with the median of $€ 150$. Thirty-one percent gave values under or equal to $€ 50$ and $15.6 \%$ between $€ 51-€ 100$. In turn, $40.1 \%$ estimated the value of well-being impacts between $€ 101-€ 500,2.2 \%$ between $€ 501-€ 999$, and $10.9 \%$ gave values equal to or above $€ 100$.

From those respondents who replied to both surveys, $28.1 \%$ gave higher values in the on-site visitor survey. Similarly, $27.9 \%$ of those respondents gave higher values in the web survey. In both cases, the median for the value change was $€ 100$. Forty-four percent of respondents did not change their mind about the monetary value of well-being effects. Therefore, for the largest share of the respondents the benefits of the park visit did not decrease after they returned home.

Web survey respondents were also asked to estimate the duration of the physical, psychological, and social well-being impacts of their visit. In general, respondents agreed that the impacts were not restricted only to the visit, but lasted longer. Psychological impacts were estimated to last the longest: $50.8 \%$ of the respondents answered that the mental impacts would last "for a long time after the visit", $45.8 \%$ estimated they would last "for some time after the visit". In turn, 3.3\% responded the visit had psychological impacts only "during the visit" and $0.2 \%$ answered the visit "did not have positive impacts". The same percentages for social impacts were the following: "for a long time" - 40.3\%, "for some time" $-46.5 \%$, "during the visit" - 10.9\%, "no positive impacts" - $2.3 \%$, and for physical impacts: "for a long time" $-13.5 \%$, "for some time" $-67.6 \%$, "during the visit" - 17.4\%, "no positive impacts" $-1.6 \%$.

\section{Impact of background and visitor variables}


Likewise to the on-site visitor survey, the perceived well-being benefits of groups of respondents of different gender, age, and education were compared. In addition, respondents' body mass indices (BMI) were calculated based on their height and weight asked in the web survey (Table S1, in Supplemental Data in the on line version of this paper). The following equation was used:

$$
B M I=\frac{\text { weight }}{\text { height }^{2}}
$$

For weight and height kilograms and meters were used, respectively. Twenty-five was used as the threshold value with those of BMI equal to 25 or lower were categorized as normal or underweight, and those above 25 as overweight.

[see Table S1 in near here]

Similarly to the visitor survey, women ranked all well-being effects higher except from Intellectual well-being (factor 2). Both genders rated Sensory satisfaction as the highest (factor 5). In contrast to the visitor survey, age groups differed from each other only in terms of Psychological and Occupational well-being (factor 1) as well as Escape (factor 3). The well-being benefits of these were rated lower by those above 65 years of age. This is explained by the importance of work related variables in both factors and the fact that most of those in the oldest age group are likely to be retired.

In terms of education, those with higher education rated Intellectual well-being (factor 2) higher than others. Thus, while in the visitor survey psychological well-being was rated higher by the more educated, this might have been due to the cognitive dimensions of psychological well-being, not necessarily restoration, emotions, or stress relief. 
Respondents who were overweight gave higher ratings to Physical well-being (factor 7) benefits than the rest. Those within the recommended or underweight category, in turn, appreciated higher the benefits of Escape (factor 3), Social well-being (factor 4), and Sensory satisfaction (factor 6).

When visitors to different protected areas were compared, the web survey gave even clearer proof that different types of parks have potentially different well-being benefits, partly due to different visitor profiles and characteristics of their visits. Similarly to the on-site survey, visitors to Kevo gave the highest ratings, and Syöte and Pyhä-Luosto visitors also gave high scores. Kurjenrahka and Repovesi visitors, in contrast, gave the lowest ratings. Overnight visitors reported higher well-being with respect to all six dimensions of well-being. Travel companion affected people's perceptions so that those who travelled alone rated Psychological and occupational well-being (factor 1) higher whereas those who had company rated Social well-being (factor 3 ) higher. While no differences between first-time and repeat visitors were found in the visitor survey, the first-time visitors gave higher scores to Intellectual well-being (factor 2), Escape (factor 3), Social well-being (factor 4) as well as Physical well-being (factor 5) benefits in the web survey.

\section{Discussion}

Our results confirm the positive effects of protected areas for visitors' psychological, physical, and social health and well-being. The perceived benefits of Finnish national parks and strict nature reserves were strong and long-lasting. Visitors highly rated their benefits during the visit as well as after returning home. Valuations in monetary terms were similar during and after the visit. On average, the health benefits of visiting a protected area were estimated to be equal to many popular commercial wellness services, but the range of monetary values was wide.

Six factors of well-being identified in the study corresponded to previous literature, but the study also revealed new aspects and deepen the understanding of different dimensions of 
well-being protected areas can offer. In terms of psychological well-being, three factors with a slightly different emphasis were distinguished. Firstly, restorative and occupational wellbeing benefits formed one factor suggesting that a visit to a protected area can increase a person's psychological capacities and positive mood (see Barton \& Pretty, 2010; Wolf \& Wohlfart, 2014). Secondly, protected areas stimulate a person's brain and skills providing intellectual well-being benefits (see Berman et al., 2008; Hartig et al., 1991). In our study also meeting new people in the park was associated with intellectual rather than social wellbeing suggesting that, at least in the Finnish context, cognitive skills can equally be about nature, activities, and social relations.

Thirdly, a visit to a protected area has a potential of providing a needed counterbalance to, and escape from, everyday life and routine environments. Escape is an aspect that has not been previously discussed as a separate well-being benefit of protected areas, but it is a common tourism motive (e.g. Iso-Ahola, 1982). Dunn Ross and Iso-Ahola (1991) suggested that the psychological benefits of recreational travel emanate from the interplay of escaping and seeking personal and interpersonal opportunities. The identification of escape as a separate well-being dimension indicates that a visit to a protected area has also potential of providing many well-being benefits looked for from other types of tourist trips. For instance, Gilbert and Abdullah (2004) showed that taking a holiday changed the sense of well-being and enabled individuals to enhance their sense of happiness (see Dolnicar, Yanamandram, \& Cliff, 2012). When operationalizing and empirically testing Iso-Ahola's (1982) motivation theory, Snepenger, King, Marshall and Uysal (2006) observed that motivational items for personal and interpersonal escape as well as for personal and interpersonal seeking were higher for the tourism experience (e.g. in a national park) than for similar recreation experience (e.g. in a local park). Weber and Anderson (2010), in turn, showed that escapism, either from personal or physical pressures, was a very important motivation for visitors in Australian urban and regional parks (see Wolf et al., 2015).

Similarly to psychological well-being, physical well-being also turned out to be more multifaceted than expected. On one hand, a visit to a protected area has positive impacts through encouraging physical activities and exercise as well as testing one's physical limits and strength (see Kaczynski \& Henderson, 2007). On the other hand, and separately from physical activity, being out in nature increases perceived well-being through pleasant and 
satisfactory sensations. These sensations were stronger than other types of physical wellbeing, which indicates that embodied experiences of nature are memorable (see Humberstone, 2011). When studying park users' own reasons for, and benefits gained from, green space usage with open-ended interview questions, Irvine, Warber, Devine-Wright and Gaston (2013) identified an important breadth to the "experience of nature"; fresh air, getting outside and sunshine emerged strongly suggesting that these intangibles were highly valued.

In general, the different health and well-being benefits were rated highly by most respondents and differences between the different groups of respondents were small. Women rated the well-being benefits higher than men, those aged between 30-65 higher than younger or older respondents, and differences were also found between normal and overweight respondents. Gender impact has also been noticed in previous studies (e.g. Lemieux et al., 2012, 2015). It may be a reflection of women showing a greater need for, or susceptibility to, experiences that foster well-being (Wolf \& Wohlfart, 2014) or of women's better health literacy (Niemelä, Ek, Eriksson-Backa, \& Huotari, 2012). This means that women are more motivated to obtain health information and are more able to reflect their own well-being.

Although differences between younger and older people have been observed in other studies (e.g. Barton \& Pretty, 2010), the small difference between age groups in our study seemed to be related to different life phase and time use patterns, rather than age or generational differences. The oldest and for the most part retired respondents gave lower ratings to the work-related benefits than others. However, this does not mean that these benefits were unimportant for the oldest age group; for instance, they rated escape with a mean value above 4. Although retired people seek less of a counterbalance to work, they may seek personal and interpersonal opportunities and escape from everyday life. For instance, Hunter-Jones and Blackburn (2007) observed that taking a holiday offered significant benefits to senior tourists in terms of personal health and social effectiveness (e.g. interaction with others, feelings of inclusion). Wolf et al. (2015) highlighted the role of guided activities in national parks in better integrating senior citizens into the community and providing opportunities to increase their well-being. Therefore, it might be more beneficial to compare groups of visitors with different motivations rather than gender, age, or education (see Konu \& Kajala, 2012). 
In general, our study suggests that protected areas have great potential for providing positive health and well-being experiences to a range of different groups despite their background, age, gender, or physical condition. In our study the respondents categorized as overweight rated the physical well-being benefits higher than those who were normal or underweight. This result may signal that a visit to a protected area can function as a motivator to encourage exercise among groups that otherwise exercise too little (see Björk et al., 2008). Physical activity may be incidental to other activities such as sightseeing, socializing, and experiencing nature, as noticed in Wolf's and Wohlfart's (2014) study.

One of the most interesting findings of our study is the difference between the perceived well-being benefits of different types of protected areas. In general, visitors to the northern parks Kevo, Syöte, and Pyhä-Luosto gave higher well-being ratings. The differences are partly explained by the characteristics of the parks, visits, and visitor profiles. These areas are located relatively far away from the major population centers, and most visitors are domestic tourists. In Kevo, over $90 \%$ of the visitors are hikers who stay in the park overnight (in a tent, lean-to shelter or open hut) while in Syöte and Pyhä-Luosto most visitors spend the night in the surrounding area. Since these visitors of the northern parks spend several days in the area, they are probably very motivated to travel to the area and prepared for the trip. Similarly, Kaikkonen and Rautiainen (2014) found that the well-being benefits perceived by fishermen and hunters were higher in the vast expanses of hunting areas in northern Finland. Lower rated Kurjenrahka and Repovesi parks, in turn, are within a day or weekend trip zone for city dwellers in southern Finland. Length of stay, and especially spending the night in the park, significantly increased the perceived well-being benefits in our study. Interestingly, first-time visitors gave higher scores to several dimensions of well-being than repeat visitors in the web survey. The differences are partly explained by the high share (71\%) of first-time visitors in Kevo Strict Nature Reserve which received the highest ratings. As Kevo is a remote destination for long-distance hikes, there are fewer repeat visitors than in other study areas. Also, motivation-based visitor segments have been shown to be different in parks (Konu \& Kajala, 2012). 
The results emphasize the importance of both close-to-home recreation and nature-based tourism destinations for human health and well-being. Protected areas located further away from people's living environments encourage people to spend longer times in nature and have potential to provide stronger benefits, including escape from everyday life, than other types of green spaces. While political attention (e.g. in EU) is increasingly directed towards urban parks and nature-based solutions in producing healthy and sustainable living environments, the contribution of rural and more peripheral natural areas to population health should not be forgotten. Visitor rates in these areas and the popularity of nature-based tourism constantly increase (see Jepson \& Sharpley, 2015; Lane \& Kastenholz, 2015). This conclusion is echoed by Weber and Anderson's (2010) result of a greater attainment for several benefits by visitors in regional rather than urban parks, emphasizing the importance of maintaining or expanding existing low development conservation zones. Meanwhile, it is important to manage problems (e.g. crowding, littering or erosion) caused by increasing visitor numbers as they may also influence perceived well-being benefits.

While our study indicates the potential dimensions of well-being in protected areas and differences between the respondent groups, our study does not decipher what exactly are the intrinsic qualities of nature itself that originate these perceptions or which qualities make benefits stronger and last longer. The importance of considering biological diversity and complexity as opposed to loosely defined "nature" when investigating the benefits of interacting with nature has increasingly been emphasized as a solution to this problem (Fuller et al., 2007; Keniger et al., 2013). Although the highest rated northern parks are located in landscapes dominated by fells or hills, any further conclusions about the influence of topography, land cover, or biodiversity on the perceived benefits would require a more detailed study. Furthermore, while the importance of different sensations and sensory satisfaction was highlighted in our study, it was also noted in Portugal (Carneiro, Lima, \& Lavrador Silva, 2015): further research on the reasons for this and its management and marketing implications is needed. In northern countries such as Finland these sensations may be very different in summer than in winter, which emphasizes the importance of studying perceived well-being benefits in different seasons. Also, Irvine et al. (2013) found in their qualitative study that when asked directly, users of urban green space gave more motivations and benefits than suggested by any existing theories or identified through the use of a closedended checklist drawn from previous research. 
In Finland and other western societies national parks and other protected areas have been increasingly assigned the new mandate as 'the fountains of health and well-being' for the urbanized population. For instance, the global movement Healthy Parks Healthy People (see: http://www.hphpcentral.com/) harnesses the power of parks and public lands in contributing to a healthy civil society. Accordingly, health and well-being benefits are increasingly used to justify financial and political support for parks and committing to the preservation of biological diversity and ecosystem services (see Stolton \& Dudley, 2010). Our findings suggest that this new mandate and objectives are well justified. At least in the Finnish context, protected areas have the potential of significantly contributing to public health. In 2013 the total value of the perceived health and well-being benefits of Finnish national parks was estimated $€ 226$ million (Vähäsarja, 2014) while the total maintenance cost of parks was over $€ 6$ million according to Parks \& Wildlife Finland. The value of the health and wellbeing benefits of all state-owned natural areas was estimated $€ 1.1$ billion while the total expenditure on Finnish health care was $€ 17.1$ billion in 2011 (ibid.). However, the health and well-being impacts of protected areas should not be taken for granted, and the new mandate should not be assigned to parks without scientific evidence and appropriate indicators to monitor the benefits.

Our results indicate that different well-being impacts of protected areas are not yet sufficiently identified. Our respondents rated highest the benefits related to escape and sensory satisfaction. These types of well-being impacts have not been thoroughly identified or discussed separately in previous studies (e.g. Lemieux et al., 2012). However, it should be acknowledged that exploratory factor analysis used in the study is driven by the items included. Additional dimensions of well-being may exist that were not adequately covered by the item set used in the study. Similarly, our study revealed differences in the perceived wellbeing between respondents of different demographic groups that may partially be explained by different capacities to interpret and reflect the survey questions. Therefore, more research, including qualitative studies, is needed to deepen the understanding of the different dimensions of health and well-being provided by protected areas and for developing appropriate and demographically sensitive/equal indicators to monitor the health and well- 
being benefits. And finally, the implications of this paper and of future studies need to be considered by Park and edge of Park planners in terms of infrastructure and especially accommodation development. Much could be learned from the comparison between low intensity and high intensity park management discussed in Getzner, Lange Vik, Brendehaug, and Lane (2014).

\section{References}

Balmford, A., Green, J. M. H., Anderson, M., Beresford, J., Huang, J., Naidoo, R., ... Manica, A. (2015). Walk on the wild side: Estimating the global magnitude of visits to protected areas. PLoS Biology, 13, e1002074. doi:10.1371/journal.pbio.1002074

Barton, J., \& Pretty, J. (2010). What is the best dose of nature and green exercise for improving mental health? A multi-study analysis. Environmental Science \& Technology, 44, 3947-3955.

van den Berg, A. E., Koole, S. L., \& van der Wulp, N. Y. (2003). Environmental preference and restoration: (How) are they related? Journal of Environmental Psychology, 23, 135-146.

Berman, M. G., Jonides, J., \& Kaplan, S. (2008). The cognitive benefits of interacting with nature. Psychological Science, 19, 1207-1212.

Björk, J., Albin, M., Grahn, P., Jacobsson, H., Ardö, J., Wadbro, J., ... Skärbäck, E. (2008). Recreational values of the natural environment in relation to neighbourhood satisfaction, physical activity, obesity and wellbeing. Journal of Epidemiology \& Community Health, 62:e2. doi:10.1136/jech.2007.062414 
Bowler, D. E., Buyung-Ali, L. M., Knight, T. M., \& Pullin, A. S. (2010). A systemic review of evidence for the added benefits to health of exposure to natural environments. BMC Public Health, 10:456. doi: 10.1186/1471-2458-10-456

Byström, J., \& Müller, D. K. (2014). Tourism labor market impacts of national parks. The case of Swedish Lapland. Zeitschrift für Wirtschaftsgeographie, 58, 115-126.

Carneiro, M. J., Lima, J., \& Lavrador Silva, A. (2015). Landscape and the rural tourism experience: Identifying key elements, addressing potential, and implications for the future. Journal of Sustainable Tourism, 23, 1217-1235.

Curtin, S. (2009). Wildlife tourism: The intangible, psychological benefits of human-wildlife encounters. Current Issues Tourism, 12, 451-474.

Dolnicar, S., Yanamandram, V., \& Cliff, K. (2012). The contribution of vacations to quality of life. Annals of Tourism Research, 39, 59-83.

Dunn Ross, E. L., \& Iso-Ahola, S. E. (1991). Sightseeing tourists' motivation and satisfaction. Annals of Tourism Research, 18, 226-237.

Fredrickson, L. M., \& Anderson, D. H. (1999). A qualitative exploration of the wilderness experience as a source of spiritual inspiration. Journal of Environmental Psychology, 19, 2139.

Fuller, R. A., Irvine, K. N., Devine-Wright, P., Warren, P. H., \& Gaston, K. J. (2007).

Psychological benefits of greenspace increase with biodiversity. Biology Letters, 3, 390-394. 
Getzner, M., Lange Vik, M., Brendehaug, E., \& Lane, B. (2014). Governance and management strategies in national parks: Implications for sustainable regional development. International Journal of Sustainable Society, 6, 82-101.

Gilbert, D., \& Abdullah, J. (2004). Holidaytaking and the sense of well-being. Annals of Tourism Research, 31, 103-121.

Hammer, T., Mose, I., Siegrist, D., \& Weixlbaumer, N. (2007). Protected areas and regional development in Europe: Towards a new model for the $21^{\text {st }}$ Century. In I. Mose (Ed.), Protected areas and regional development in Europe. Towards a new model for the $21^{\text {st }}$ Century (pp. 233-246). Aldershot: Ashgate.

Han, K. (2010). An exploration or relationships among the responses to natural scenes: Scenic beauty, preference and restoration. Environment and Behavior, 42, 243-270.

Hanski, I., von Hertzen, L., Fyhrquist, N., Koskinen, K., Torppa, K., Laatikainen, T., ... Haahtela, T. (2012). Environmental biodiversity, human microbiota, and allergy are interrelated. PNAS, 109, 8334-8339.

Hansmann, R., Hug, S., \& Seeland, K. (2007). Restoration and stress relief through physical activities in forests and parks. Urban Forestry Urban Greening, 6, 213-225.

Hartig, T., Mang, M., \& Evans, G. W. (1991). Restorative effects of natural environment experiences. Environment \& Behavior, 23, 3-26. 
Hartig, T., Evans, G. W., Jamner, L. D., Davis, D. S., \& Gärling, T. (2003). Tracking restoration in natural and urban field settings. Journal of Environmental Psychology, 23, $109-123$.

Hartig, T., Kaiser, F. G., \& Strumse, E. (2007). Psychological restoration in nature as a source of motivation for ecological behaviour. Environmental Conservation, 34, 291-299.

Health Council of the Netherlands and Dutch Advisory Council for Research on Spatial Planning, Nature and the Environment. (2004). Nature and health. The influence of nature on social, psychological and physical well-being. The Hague: Health Council of the Netherlands and RMNO. Retrieved (20.9.2016) from https://www.gezondheidsraad.nl/sites/default/files/Nature_and_health.pdf

Hjalager, A-M., Konu, H., Huijbens, E. H., Björk, P., Flagestad, A., Nordin, S., \& Tuohino, A. (2011). Innovation and re-branding Nordic wellbeing tourism. Nordic Innovation Centre. Retrieved (20.9.2016) from http://www.nordicinnovation.org/Global/_Publications/Reports/2011/2011_NordicWellbeing Tourism_report.pdf

Humberstone, B. (2011). Embodiment and social and environmental action in nature-based sport: Spiritual spaces. Leisure Studies, 30, 495-512.

Hunter-Jones, P., \& Blackburn, A. (2007). Understanding the relationship between holidaytaking and self-assessed health: An exploratory study of senior tourism. International Journal of Consumer Studies, 31, 509-516.

Irvine K. N., \& Warber, S. L. (2002). Greening healthcare: Practicing as if the natural environment really mattered. Alternative Therapies in Health and Medicine, 8, 76-83. 
Irvine, K. N., Warber, S. L., Devine-Wright, P., \& Gaston, K. J. (2013). Understanding urban green space as a health resource: A qualitative comparison of visit motivation and derived effects among park users in Sheffield, UK. International Journal of Environmental Research and Public Health, 10, 417-442.

Iso-Ahola, S. E. (1982). Toward a social psychological theory of tourism motivation: A rejoinder. Annals of Tourism Research, 9, 256-262.

Jepson, D., \& Sharpley, R. (2015). More than sense of place? Exploring the emotional dimension of rural tourism experiences. Journal of Sustainable Tourism, 23, 1157-1178.

Kaczynski, A. T., \& Henderson, K. A. (2007). Environmental correlates of physical activity: A review of evidence about parks and recreation. Leisure Sciences, 29, 315-354.

Kaikkonen, H., \& Rautiainen, M. (2014). Terveyttä ja hyvinvointia valtion mailtatarkastelussa metsästäjät ja kalastajat [Health and well-being in State-owned land - study of hunters and fisherman]. Nature Protection Publications of Metsähallitus. Series A 209. Vantaa: Metsähallitus. Retrieved (20.9.2016) from https://julkaisut.metsa.fi/assets/pdf/lp/Asarja/a209.pdf

Kaikkonen, H., Virkkunen, V., Kajala, L., Erkkonen, J., Aarnio, M., \& Korpelainen, R. (2014). Terveyttä ja hyvinvointia kansallispuistoista - tutkimus kävijöiden kokemista vaikutuksista [Health and well-being from Finnish national parks - A study on benefits perceived by visitors]. Executive summary in English. Nature Protection Publications of Metsähallitus. Series A 208. Vantaa: Metsähallitus. Retrieved (20.9.2016) from https://julkaisut.metsa.fi/assets/pdf/lp/Asarja/a208.pdf 
Kaplan, R. (2001). The nature of the view from home: Psychological benefits. Environment and Behavior, 33, 507-542.

Karjalainen, E., Sarjala, T., \& Raitio, H. (2010). Promoting human health through forests: Overview and major challenges. Environmental Health and Preventive Medicine, 15, 1-8.

Keniger, L., Gaston, K., Irvine, K. N., \& Fuller, R. (2013). What are the benefits of interacting with nature? International Journal of Environmental Research and Public Health, $10,913-935$.

Konu, H., \& Kajala, L. (2012). Segmenting protected area visitors based on their motivations. Nature Protection Publications by Metsähallitus. Series A 194. Vantaa: Metsähallitus. Retrieved (20.9.2016) from https://julkaisut.metsa.fi/assets/pdf/lp/Asarja/a194.pdf

Korpela, K., Borodulin, K., Neuvonen, M., Paronen, O., \& Tyrväinen, L. (2014). Analyzing the mediators between nature-based outdoor recreation and emotional well-being. Journal of Environmental Psychology, 37, 1-7.

Kuo, F. E., \& Sullivan, W. C. (2001). Aggression and violence in the inner city. Effects of environment via mental fatigue. Environment and Behavior, 33, 543 -571.

Kuo F. E., \& Taylor A. F. (2004). A potential natural treatment for attentiondeficit/hyperactivity disorder: Evidence from a national study. American Journal of Public Health, 94, 1580-6. 
Lane, B., \& Kastenholz, E. (2015). Rural tourism: The evolution of practice and research approaches - towards a new generation concept? Journal of Sustainable Tourism, 23, 11331156.

Lee, J., Li, Q., Tyrväinen, L., Tsunetsugu, Y., Park, B-J., Kagawa, T., \& Miyazaki, Y. (2012). Nature therapy and preventive medicine. In J. Maddock (Ed.), Public health - Social and behavioral health, InTech Open (pp. 325-350). Retrieved (20.9.2016) from http://www.intechopen.com/books/howtoreference/public-health-social-and-behavioralhealth/nature-therapy-and-preventive-medicine

Lemieux, C., Eagles, P., Slocombe, D., Doherty, S., Elliott, S., \& Mock S. (2012). Human health and well-being motivations and benefits associated with protected area experiences: an opportunity for transforming policy and management in Canada. PARKS: the International Journal of Conservation and Protected Areas, 18, 71-86.

Lemieux, C. J., Doherty, S. T., Eagles, P. F .J., Gould, J., Hvenegaard, G. T., Nisbet, E., \& Groulx, M. W. (2015). Healthy outside-healthy inside: The human health and well-being benefits of Alberta's protected areas - towards a benefits-based management agenda. Ottawa: CCEA Secretariat. Retrieved (20.9.2016) from http://scholars.wlu.ca/cgi/viewcontent.cgi?article=1024\&context=geog_faculty

Maller, C. J. (2009). Promoting children's mental, emotional and social health through contact with nature: a model. Health Education, 109, 522-543.

Maller, C., Townsend, M., Brown, P., St Leger, L., Henderson-Wilson, C., Pryor, A., ... Moore, M. (2008). Healthy parks healthy people: The health benefits of contact with nature in a park context. A review of relevant literature (2nd ed.). Melbourne: Deakin University and Parks Victoria. Retrieved (20.9.2016) from http://www.deakin.edu.au/_data/assets/pdf_file/0016/310750/HPHP-2nd-Edition.pdf 
Mayer, M. (2014). Can nature-based tourism benefits compensate for the costs of national parks? A study of the Bavarian Forest National Park, Germany. Journal of Sustainable Tourism, 22, 561-583.

Metsähallitus. (2016a). Principles of Protected Area Management in Finland. Nature Protection Publications of Metsähallitus. Series B 217. Vantaa: Metsähallitus. Retrieved (20.9.2016) https://julkaisut.metsa.fi/assets/pdf/lp/Bsarja/b217.pdf

Metsähallitus. (2016b). Kansallispuistojen, valtion retkeilyalueiden ja muiden virkistyskäytöllisesti merkittävimpien Metsähallituksen hallinnoimien suojelualueiden ja retkeilykohteiden käyntimäärät vuonna 2015 [Number of visits in national parks, national hiking areas and other conservation and recreation areas managed by Metsähallitus in 2015]. Retrieved (20.9.2016) from http://www.metsa.fi/documents/10739/3335805/kayntimaarat2015_fi.pdf/0e3f3835-17e84a99-9b4c-51f1b1d1b9a5

Moore, M., Townsend, M., \& Oldroyd, J. (2006). Linking human and ecosystem health: The benefits of community involvement in conservation groups. EcoHealth, 3, 255-261.

Niemelä, R., Ek, S., Eriksson-Backa, K. \& Huotari, M-L. (2012). A screening tool for assessing everyday health information literacy. Libri, 62, 125-134.

Nilsson, K., Baines, C., \& Konijnendik, C. C. (2007). Health and the natural outdoors. Larnaka: COST Strategic Workshop, Final Report. Retrieved (20.9.2016) from http://www.umb.no/statisk/greencare/general/strategic_workshop_final_report.pdf 
Pasanen, T., Tyrväinen, L., \& Korpela, K. M. (2014). The relationship between perceived health and physical activity indoors, outdoors in built environments, and outdoors in nature. Applied Psychology: Health and Well-Being, 6, 324-346.

Pretty, J., Peacock, J., Hine, R., Sellens, M., South, N., \& Griffin, M. (2007). Green exercise in the UK Countryside: Effects on health and psychological well-being, and implications for policy and planning. Journal of Environmental Planning and Management, 50, 211-231.

Puhakka, R., \& Saarinen, J. (2013). New role of tourism in national park planning in Finland. The Journal of Environment and Development, 22, 411-434.

Puustinen, J., Pouta, E., Neuvonen, M., \& Sievänen, T. (2009). Visits to national parks and the provision of natural and man-made recreation and tourism resources. Journal of Ecotourism, 8, 18-31.

Shin, W. S., Yeoun, P. S., Yoo, R. W., \& Shin, C. S. (2010). Forest experience and psychological health benefits. Environmental Health and Preventive Medicine, 15, 38-47.

Siikamäki, P., Kangas, K., Paasivaara, A., \& Schoderus, S. (2015). Biodiversity attracts visitors to national parks. Biodiversity and Conservation, 24, 2521-2534.

Snepenger, D., King, J., Marshall, E., \& Uysal, M. (2006). Modeling Iso-Ahola's motivation theory in the tourism context. Journal of Travel Research, 45, 140-149.

Stolton, S., \& Dudley, N. (2010). Vital sites: The contribution of protected areas to human health. The Arguments for Protection Series. Gland: WWF. Retrieved (20.9.2016) from http://assets.panda.org/downloads/vital_sites.pdf 
Tsunetsugu, Y., Park, B. J., Ishii, H., Hirano, H., Kagawa, T., \& Miyazaki, Y. (2007).

Physiological effects of Shinrin-yoku (taking in the atmosphere of the forest) in an oldgrowth broadleaf forest in Yamagata prefecture, Japan. Journal of Physiological Anthropology, 26, 135-142.

Tyrväinen, L., Ojala, A., Korpela, K., Lanki, T., Tsunetsugu, Y., \& Kagawa, T. (2014). The influence of urban green environments on stress relief measures: A field experiment. Journal of Environmental Psychology, 38, 1-9.

Vähäsarja, V. (2014). Luontoympäristön terveys- ja hyvinvointivaikutusten taloudellinen arvottaminen [Assessment of the financial value of the health and well-being benefits of natural environments]. Nature Protection Publications of Metsähallitus. Series A 210. Vantaa: Metsähallitus. Retrieved (20.9.2016) from https://julkaisut.metsa.fi/assets/pdf/lp/Asarja/a210.pdf

Wall Reinius, S., \& Fredman, P. (2007). Protected areas as attractions. Annals of Tourism Research, 34, 839-854.

Weber, D., \& Anderson, D. (2010). Contact with nature: Recreation experience preferences in Australian parks. Annals of Leisure Research, 13, 46-69.

Wolf, I. D., \& Wohlfart, T. (2014). Walking, hiking and running in parks: A multidisciplinary assessment of health and well-being benefits. Landscape and Urban Planning, 130, 89-103.

Wolf, I. D., Stricker, H. K., \& Hagenloh, G. (2015). Outcome-focused national park experience management: Transforming participants, promoting social well-being, and fostering place attachment. Journal of Sustainable Tourism, 23, 358-381. 
Table 1. Characteristics of study areas.

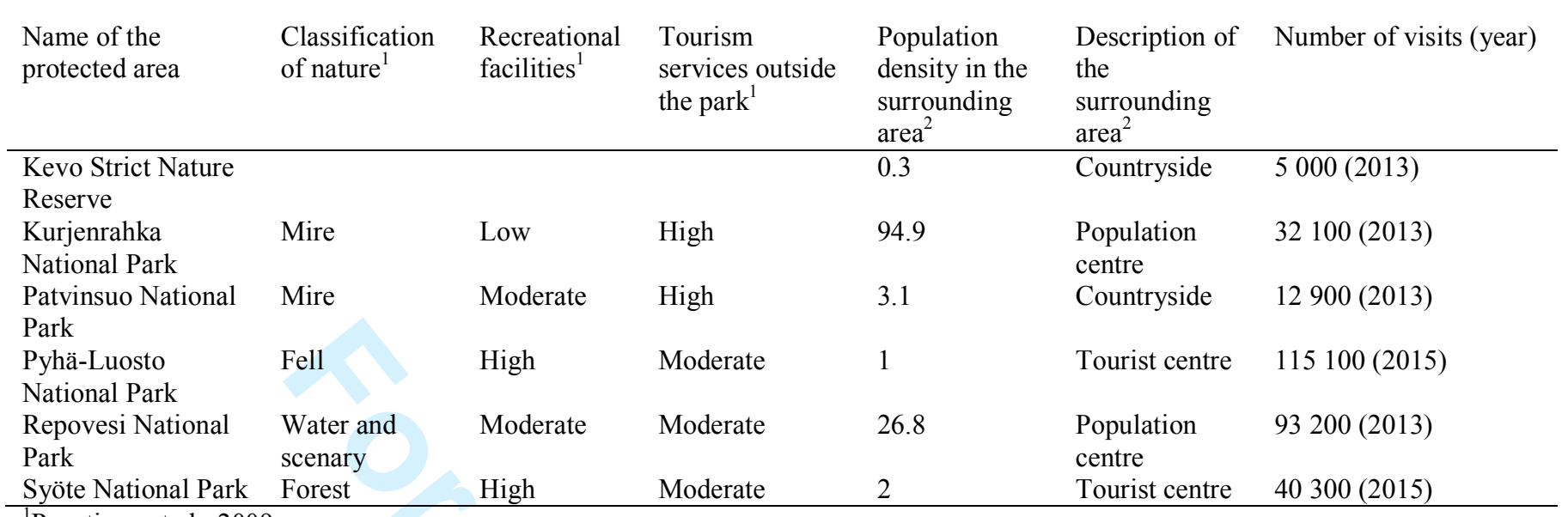

${ }^{\mathrm{I}}$ Puustinen et al., 2009

${ }^{2}$ Inhabitans per $\mathrm{km}^{2}$; Statistics Finland and Parks \& Wildlife Finland 2011 
Table 2. Data used in the study.

Web survey $\mathrm{N}$ (year)

290 (2013)

132 (2013)

$50(2013)$

$\begin{array}{lll}\text { Pyhä-Luosto National Park } & 760(2015-2016) & 109(2015-2016) \\ \text { Repovesi National Park } & 902(2013-2014) & 399(2013-2014)\end{array}$

$\begin{array}{lll}\text { Syöte National Park } & 375(2015) & 74(2015)\end{array}$


Table 3. Demographic characteristics of survey respondents.

\begin{tabular}{ll|rr|rr}
\hline & & \multicolumn{2}{|c|}{ On-site visitor survey } & \multicolumn{2}{c}{ Web survey } \\
& & $\mathrm{N}$ & $\%$ & $\mathrm{~N}$ & $\%$ \\
\hline Gender & Male & 1409 & 44.7 & 453 & 43.3 \\
& Female & 1743 & 55.3 & 590 & 56.7 \\
\hline Age & Under 30 years & 650 & 20.8 & 214 & 20.7 \\
& 30-44 years & 945 & 30.2 & 337 & 32.6 \\
& 45-64 years & 1225 & 39.2 & 411 & 39.7 \\
& 65 years or older & 305 & 9.8 & 73 & 7.1 \\
\hline Education & Less than bachelors & 1537 & 49.4 & 465 & 45.0 \\
& Bachelors or higher & 1572 & 50.6 & 569 & 55.0 \\
\hline BMI & Normal or underweight & & & 594 & 57.3 \\
& Overweight & & & 443 & 42.7 \\
\hline
\end{tabular}


Table 4. Descriptive statistics and tests of significance for the ratings of health and well-being benefits between different groups of the on-site visitor survey.

\begin{tabular}{|c|c|c|c|}
\hline & Social well-being & Mental well-being & Physical well-being \\
\hline $\mathrm{N}$ & 3116 & 3115 & 3118 \\
\hline Mean & 4.23 & 4.41 & 4.43 \\
\hline Std. Deviation & 0.80 & 0.70 & 0.69 \\
\hline Gender (p-value) & $<0.01 * *$ & $<0.01 * *$ & $<0.01 * *$ \\
\hline $\operatorname{Male}(\mathrm{N})$ & 1384 & 1382 & 1384 \\
\hline Mean & 4.10 & 4.32 & 4.32 \\
\hline Std. Deviation & 0.82 & 0.72 & 0.72 \\
\hline Female $(\mathrm{N})$ & 1721 & 1722 & 1723 \\
\hline Mean & 4.32 & 4.47 & 4.51 \\
\hline Std. Deviation & 0.77 & 0.67 & 0.65 \\
\hline Age (p-value) & $<0.01 * *$ & $<0.01 * *$ & $0.024 *$ \\
\hline Under 30 years $(\mathrm{N})$ & 647 & 646 & 647 \\
\hline Mean & 4.13 & 4.34 & 4.37 \\
\hline Std. Deviation & 0.85 & 0.77 & 0.69 \\
\hline $30-44 \operatorname{years}(\mathrm{N})$ & 938 & 940 & 937 \\
\hline Mean & 4.28 & 4.48 & 4.44 \\
\hline Std. Deviation & 0.77 & 0.64 & 0.69 \\
\hline $45-64 \operatorname{years}(\mathrm{N})$ & 1205 & 1203 & 1208 \\
\hline Mean & 4.26 & 4.43 & 4.46 \\
\hline Std. Deviation & 0.78 & 0.66 & 0.67 \\
\hline 65 years or older $(\mathrm{N})$ & 292 & 292 & 292 \\
\hline Mean & 4.10 & 4.22 & 4.37 \\
\hline Std. Deviation & 0.81 & 0.74 & 0.73 \\
\hline Education (p-value) & 0.063 & $0.008^{*}$ & 0.887 \\
\hline Less than bachelors $(\mathrm{N})$ & 1519 & 1515 & 1518 \\
\hline Mean & 4.20 & 4.37 & 4.42 \\
\hline
\end{tabular}




\begin{tabular}{|c|c|c|c|}
\hline Std. Deviation & 0.80 & 0.71 & 0.71 \\
\hline Bachelors or higher $(\mathrm{N})$ & 1553 & 1556 & 1556 \\
\hline Mean & 4.25 & 4.44 & 4.43 \\
\hline Std. Deviation & 0.81 & 0.68 & 0.68 \\
\hline$B M I$ (p-value) & 0.120 & 0.600 & 0.746 \\
\hline Normal or underweight $(\mathrm{N})$ & 587 & 587 & 588 \\
\hline Mean & 4.33 & 4.47 & 4.47 \\
\hline Std. Deviation & 0.76 & 0.65 & 0.67 \\
\hline Overweight $(\mathrm{N})$ & 438 & 439 & 439 \\
\hline Mean & 4.27 & 4.46 & 4.46 \\
\hline Std. Deviation & 0.74 & 0.61 & 0.64 \\
\hline Park & $0.009^{*}$ & 0.081 & $0.001 * *$ \\
\hline Kevo Strict Nature Reserve $(\mathrm{N})$ & 516 & 514 & 514 \\
\hline Mean & 4.22 & 4.47 & 4.47 \\
\hline Std. Deviation & 0.77 & 0.64 & 0.64 \\
\hline Kurjenrahka National Park (N) & 404 & 404 & 405 \\
\hline Mean & 4.13 & 4.38 & 4.33 \\
\hline Std. Deviation & 0.88 & 0.71 & 0.72 \\
\hline Patvinsuo National Park (N) & 210 & 210 & 210 \\
\hline Mean & 4.37 & 4.49 & 4.47 \\
\hline Std. Deviation & 0.72 & 0.65 & 0.68 \\
\hline Pyhä-Luosto National Park (N) & 743 & 746 & 746 \\
\hline Mean & 4.17 & 4.38 & 4.43 \\
\hline Std. Deviation & 0.81 & 0.72 & 0.68 \\
\hline Repovesi National Park (N) & 882 & 880 & 882 \\
\hline Mean & 4.27 & 4.37 & 4.38 \\
\hline Std. Deviation & 0.78 & 0.72 & 0.72 \\
\hline Syöte National Park (N) & 361 & 361 & 361 \\
\hline Mean & 4.26 & 4.43 & 4.52 \\
\hline
\end{tabular}




\begin{tabular}{|c|c|c|c|}
\hline Std. Deviation & 0.79 & 0.66 & 0.65 \\
\hline Overnight ( $\mathrm{p}$-value) & 0.342 & $0.004 *$ & 0.370 \\
\hline Overnight visitors $(\mathrm{N})$ & 1161 & 1160 & 1161 \\
\hline Mean & 4.25 & 4.45 & 4.44 \\
\hline Std. Deviation & 0.78 & 0.68 & 0.68 \\
\hline Day visitors $(\mathrm{N})$ & 1777 & 1777 & 1779 \\
\hline Mean & 4.21 & 4.38 & 4.41 \\
\hline Std. Deviation & 0.81 & 0.71 & 0.70 \\
\hline Alone or group (p-value) & $0.004 *$ & 0.084 & $0.042 *$ \\
\hline Alone $(\mathrm{N})$ & 214 & 216 & 216 \\
\hline Mean & 4.05 & 4.50 & 4.53 \\
\hline Std. Deviation & 0.92 & 0.63 & 0.61 \\
\hline Group $(\mathrm{N})$ & 2902 & 2899 & 2902 \\
\hline Mean & 4.24 & 4.40 & 4.42 \\
\hline Std. Deviation & 0.79 & 0.70 & 0.70 \\
\hline First time visitor (p-value) & 0.178 & 0.879 & 0.760 \\
\hline First time visitor $(\mathrm{N})$ & 1212 & 1211 & 1212 \\
\hline Mean & 4.20 & 4.40 & 4.42 \\
\hline Std. Deviation & 0.82 & 0.73 & 0.69 \\
\hline Repeat visitor $(\mathrm{N})$ & 1904 & 1904 & 1906 \\
\hline Mean & 4.24 & 4.41 & 4.43 \\
\hline Std. Deviation & 0.79 & 0.68 & 0.69 \\
\hline
\end{tabular}

*Result significant at 0.05 level

**Result significant at 0.01 level 
Table 5. Factor loadings.

\begin{tabular}{|c|c|c|c|c|c|c|}
\hline \multirow{2}{*}{ Scale items } & \multicolumn{6}{|c|}{ Factors } \\
\hline & $\begin{array}{l}\text { Psychol } \\
\text { ogical } \\
\text { and } \\
\text { occupati } \\
\text { onal }\end{array}$ & $\begin{array}{l}\text { Intellect } \\
\text { ual }\end{array}$ & Escape & Social & Physical & $\begin{array}{l}\text { Sensory } \\
\text { satis- } \\
\text { faction }\end{array}$ \\
\hline Total variance explained & 59.5 & & & & & \\
\hline Cronbach's $\%$ (alfa) & 0.86 & 0.70 & 0.70 & 0.82 & 0.78 & 0.83 \\
\hline My vitality and energy increased & 0.614 & & & & & \\
\hline I got better hope for tomorrow & 0.766 & & & & & \\
\hline My concentration improved & 0.764 & & & & & \\
\hline My self-confidence increased & 0.679 & & & & & \\
\hline I calmed down & 0.568 & & & & & \\
\hline My life was put into perspective & 0.751 & & & & & \\
\hline My work motivation improved & 0.523 & & & & & \\
\hline $\begin{array}{l}\text { My motivation for everyday life } \\
\text { improved }\end{array}$ & 0.600 & & & & & \\
\hline I learned new skills & & 0.709 & & & & \\
\hline I learned more about nature & & 0.731 & & & & \\
\hline $\begin{array}{l}\text { My interest towards nature } \\
\text { increased }\end{array}$ & & 0.565 & & & & \\
\hline $\begin{array}{l}\text { I enjoyed meeting new people } \\
\text { during the visit }\end{array}$ & & 0.601 & & & & \\
\hline I forgot everyday worries & & & 0.686 & & & \\
\hline $\begin{array}{l}\text { I had a chance to get away from } \\
\text { work }\end{array}$ & & & 0.775 & & & \\
\hline $\begin{array}{l}\text { I had a change to get away from } \\
\text { everday }\end{array}$ & & & 0.700 & & & \\
\hline $\begin{array}{l}\text { I enjoyed spending time with } \\
\text { people I cherish }\end{array}$ & & & & 0.875 & & \\
\hline $\begin{array}{l}\text { I enjoyed shared activities with } \\
\text { people I cherish }\end{array}$ & & & & 0.873 & & \\
\hline $\begin{array}{l}\text { I found it easier to talk about } \\
\text { personal matters in nature }\end{array}$ & & & & 0.555 & & \\
\hline $\begin{array}{l}\text { Having company increased my } \\
\text { feeling of security }\end{array}$ & & & & 0.659 & & \\
\hline $\begin{array}{l}\text { Being in nature fostered my } \\
\text { relationship with people I cherish }\end{array}$ & & & & 0.746 & & \\
\hline $\begin{array}{l}\text { During my visit to the area I } \\
\text { exercised more than in everyday } \\
\text { life }\end{array}$ & & & & & 0823 & \\
\hline $\begin{array}{l}\text { I was able to test my physical } \\
\text { strenght }\end{array}$ & & & & & 0.730 & \\
\hline $\begin{array}{l}\text { I felt that nature excercise } \\
\text { improved my physical condition }\end{array}$ & & & & & 0.800 & \\
\hline $\begin{array}{l}\text { I felt my physical well-being } \\
\text { improved }\end{array}$ & & & & & 0.593 & \\
\hline I enjoyed silence & & & & & & 0.689 \\
\hline I enjoyed sounds of nature & & & & & & 0.830 \\
\hline I enjoyed the fragrance of nature & & & & & & 0.828 \\
\hline It felt good to breathe fresh air & & & & & & 0.759 \\
\hline I enjoyed beautiful nature & & & & & & 0.629 \\
\hline $\begin{array}{l}\text { The feel of nature was pleasant } \\
\text { (wind on my face. soft moss. } \\
\text { shapes of different surfaces) }\end{array}$ & & & & & & 0.653 \\
\hline
\end{tabular}


Table S1. Descriptive statistics and tests of significance for the ratings of health and wellbeing benefits between different groups of the web survey.

\begin{tabular}{|c|c|c|c|c|c|c|}
\hline & $\begin{array}{l}\text { Psychologic } \\
\text { al and } \\
\text { occupational }\end{array}$ & Intellectual & Escape & Social & Physical & $\begin{array}{l}\text { Sensory } \\
\text { satisfaction }\end{array}$ \\
\hline$\overline{\mathrm{N}}$ & 1029 & 1034 & 1045 & 1041 & 1040 & 1040 \\
\hline Mean & 3.89 & 3.59 & 4.53 & 4.02 & 4.00 & 4.79 \\
\hline Std. Deviation & 0.59 & 0.73 & 0.56 & 0.74 & 0.78 & 0.34 \\
\hline Gender (p-value) & $0.001^{* *}$ & 0.121 & $<0.01 * *$ & $<0.01 * *$ & $<0.01 * *$ & $<0.01 * *$ \\
\hline Male $(\mathrm{N})$ & 446 & 447 & 447 & 446 & 446 & 447 \\
\hline Mean & 3.83 & 3.55 & 4.46 & 3.87 & 3.87 & 4.72 \\
\hline Std. Deviation & 0.56 & 0.69 & 0.56 & 0.74 & 0.77 & 0.39 \\
\hline Female (N) & 572 & 577 & 587 & 584 & 583 & 583 \\
\hline Mean & 3.94 & 3.62 & 4.58 & 4.13 & 4.10 & 4.85 \\
\hline Std. Deviation & 0.61 & 0.75 & 0.55 & 0.73 & 0.77 & 0.29 \\
\hline Age (p-value) & $0.014^{*}$ & 0.847 & $<0.01 * *$ & 0.051 & 0.911 & 0.114 \\
\hline $\begin{array}{l}\text { Under } 30 \text { years } \\
(\mathrm{N})\end{array}$ & 212 & 210 & 214 & 213 & 212 & 213 \\
\hline Mean & 3.93 & 3.60 & 4.57 & 4.07 & 4.00 & 4.80 \\
\hline Std. Deviation & 0.56 & 0.82 & 0.53 & 0.71 & 0.82 & 0.35 \\
\hline $30-44 \operatorname{years}(\mathrm{N})$ & 330 & 330 & 335 & 334 & 333 & 336 \\
\hline Mean & 3.94 & 3.57 & 4.60 & 4.08 & 4.00 & 4.79 \\
\hline Std. Deviation & 0.60 & 0.72 & 0.51 & 0.72 & 0.77 & 0.35 \\
\hline $45-64 \operatorname{years}(\mathrm{N})$ & 398 & 404 & 407 & 405 & 405 & 405 \\
\hline Mean & 3.88 & 3.60 & 4.53 & 3.97 & 4.02 & 4.81 \\
\hline Std. Deviation & 0.59 & 0.68 & 0.58 & 0.79 & 0.77 & 0.30 \\
\hline $\begin{array}{l}65 \text { years or older } \\
(\mathrm{N})\end{array}$ & 70 & 71 & 70 & 71 & 72 & 69 \\
\hline Mean & 3.71 & 3.56 & 4.12 & 3.91 & 3.97 & 4.67 \\
\hline Std. Deviation & 0.53 & 0.72 & 0.61 & 0.70 & 0.78 & 0.43 \\
\hline Education (p- & 0.266 & $0.009^{*}$ & 0.917 & 0.880 & 0.086 & 0.104 \\
\hline
\end{tabular}




\begin{tabular}{|c|c|c|c|c|c|c|}
\hline value) & & & & & & \\
\hline $\begin{array}{l}\text { Less than } \\
\text { bachelors }(\mathrm{N})\end{array}$ & 453 & 457 & 459 & 456 & 460 & 457 \\
\hline Mean & 3.92 & 3.65 & 4.53 & 4.02 & 4.05 & 4.80 \\
\hline Std. Deviation & 0.59 & 0.70 & 0.57 & 0.77 & 0.74 & 0.34 \\
\hline $\begin{array}{l}\text { Bachelors or } \\
\text { higher }(\mathrm{N})\end{array}$ & 556 & 557 & 566 & 566 & 560 & 564 \\
\hline Mean & 3.87 & 3.53 & 4.53 & 4.02 & 3.95 & 4.78 \\
\hline Std. Deviation & 0.59 & 0.75 & 0.56 & 0.74 & 0.81 & 0.34 \\
\hline$B M I$ (p-value) & 0.208 & 0.762 & $0.009^{*}$ & $0.024^{*}$ & $0.022 *$ & $0.034^{*}$ \\
\hline $\begin{array}{l}\text { Normal or } \\
\text { underweight }(\mathrm{N})\end{array}$ & 584 & 582 & 591 & 588 & 588 & 589 \\
\hline Mean & 3.87 & 3.58 & 4.58 & 4.06 & 3.95 & 4.81 \\
\hline Std. Deviation & 0.60 & 0.75 & 0.52 & 0.74 & 0.79 & 0.32 \\
\hline Overweight $(\mathrm{N})$ & 428 & 435 & 437 & 436 & 436 & 434 \\
\hline Mean & 3.93 & 3.61 & 4.48 & 3.97 & 4.07 & 4.77 \\
\hline Std. Deviation & 0.56 & 0.69 & 0.60 & 0.75 & 0.76 & 0.36 \\
\hline Park & $0.003^{*}$ & $<0.01 * *$ & $<0.01^{* *}$ & $0.039^{*}$ & $<0.01 * *$ & $0.001 * *$ \\
\hline Kevo Strict & & & & & & \\
\hline $\begin{array}{l}\text { Nature Reserve } \\
\text { (N) }\end{array}$ & $\begin{array}{l}285 \\
4\end{array}$ & $\begin{array}{l}285 \\
3.80\end{array}$ & $\begin{array}{l}289 \\
4.68\end{array}$ & $\begin{array}{l}288 \\
4.04\end{array}$ & $\begin{array}{l}290 \\
4.30\end{array}$ & $\begin{array}{l}290 \\
4.86\end{array}$ \\
\hline Mean & 0.59 & 0.70 & 0.48 & 0.81 & 0.69 & 0.28 \\
\hline Std. Deviation & & & & & & \\
\hline Kurjenrahka & & & & & & \\
\hline $\begin{array}{l}\text { National Park } \\
\text { (N) }\end{array}$ & $\begin{array}{l}130 \\
3.86\end{array}$ & $\begin{array}{l}130 \\
3.31\end{array}$ & $\begin{array}{l}130 \\
4.38\end{array}$ & $\begin{array}{l}130 \\
3.86\end{array}$ & $\begin{array}{l}130 \\
3.62\end{array}$ & $\begin{array}{l}129 \\
4.80\end{array}$ \\
\hline Mean & 0.56 & 0.64 & 0.59 & 0.80 & 0.81 & 0.31 \\
\hline $\begin{array}{l}\text { Std. Deviation } \\
\text { Patvinsuo }\end{array}$ & & & & & & \\
\hline $\begin{array}{l}\text { National Park } \\
\text { (N) }\end{array}$ & $\begin{array}{l}50 \\
3.85\end{array}$ & $\begin{array}{l}50 \\
3.79\end{array}$ & $\begin{array}{l}50 \\
4.58\end{array}$ & $\begin{array}{l}50 \\
3.88\end{array}$ & $\begin{array}{l}50 \\
3.70\end{array}$ & $\begin{array}{l}50 \\
4.82\end{array}$ \\
\hline Mean & 0.56 & 0.58 & 0.45 & 0.96 & 0.82 & 0.31 \\
\hline
\end{tabular}

Std. Deviation 
Pyhä-Luosto

National Park

(N)

Mean

106

107

107

108

108

105

$3.91 \quad 3.63$

4.53

4.17

4.08

4.81

Std. Deviation

$\begin{array}{ll}0.58 & 0.64\end{array}$

0.61

0.60

0.69

0.35

Repovesi

National Park

386

389

395

391

390

396

(N)

Mean

3.82

3.49

4.47

4.03

3.86

4.74

Std. Deviation

0.58

0.75

0.59

0.67

0.77

0.38

\begin{tabular}{|c|c|c|c|c|c|c|}
\hline $\begin{array}{l}\text { Syöte National } \\
\text { Park (N) }\end{array}$ & 72 & 73 & 74 & 74 & 72 & 70 \\
\hline Mean & 3.93 & 3.55 & 4.50 & 4.02 & 4.33 & 4.76 \\
\hline Std. Deviation & 0.64 & 0.78 & 0.53 & 0.75 & 0.62 & 0.32 \\
\hline $\begin{array}{l}\text { Overnight (p- } \\
\text { value) }\end{array}$ & $<0.01 * *$ & $<0.01 * *$ & $<0.01^{* *}$ & $0.002 *$ & $<0.01 * *$ & $0.004 *$ \\
\hline $\begin{array}{l}\text { Overnight } \\
\text { visitors }(\mathrm{N})\end{array}$ & 501 & 501 & 505 & 504 & 505 & 504 \\
\hline Mean & 3.96 & 3.75 & 4.62 & 4.07 & 4.17 & 4.81 \\
\hline Std. Deviation & 0.57 & 0.72 & 0.52 & 0.76 & 0.74 & 0.33 \\
\hline Day visitors $(\mathrm{N})$ & 490 & 494 & 500 & 497 & 496 & 496 \\
\hline Mean & 3.83 & 3.40 & 4.44 & 3.96 & 3.80 & 4.79 \\
\hline Std. Deviation & 0.60 & 0.68 & 0.58 & 0.73 & 0.78 & 0.35 \\
\hline $\begin{array}{l}\text { Alone or group } \\
\text { (p-value) }\end{array}$ & $0.012 *$ & 0.303 & 0.99 & $<0.01 * *$ & 0.198 & 0.135 \\
\hline Alone $(\mathrm{N})$ & 84 & 86 & 87 & 87 & 85 & 86 \\
\hline Mean & 4.04 & 3.67 & 4.53 & 2.71 & 4.09 & 4.86 \\
\hline Std. Deviation & 0.57 & 0.64 & 0.59 & 0.93 & 0.79 & 0.25 \\
\hline $\operatorname{Group}(\mathrm{N})$ & 945 & 948 & 958 & 954 & 955 & 954 \\
\hline Mean & 3.88 & 3.58 & 4.53 & 4.14 & 3.99 & 4.79 \\
\hline Std. Deviation & 0.59 & 0.73 & 0.56 & 0.60 & 0.78 & 0.35 \\
\hline $\begin{array}{l}\text { First time visitor } \\
\text { (p-value) }\end{array}$ & 0.082 & $<0.01 * *$ & $<0.01 * *$ & $0.001 *$ & $<0.01 * *$ & 0.531 \\
\hline
\end{tabular}




$\begin{array}{lcccccc}\begin{array}{l}\text { First time visitor } \\ \text { (N) }\end{array} & 416 & 423 & 425 & 424 & 424 & 424 \\ \text { Mean } & 3.93 & 3.74 & 4.61 & 4.11 & 4.18 & 4.81 \\ \text { Std. Deviation } & 0.62 & 0.72 & 0.53 & 0.69 & 0.73 & 0.32 \\ \begin{array}{l}\text { Repeat visitor } \\ \text { (N) }\end{array} & 613 & 611 & 620 & 617 & 616 & 616 \\ \text { Mean } & 3.87 & 3.48 & 4.48 & 3.95 & 3.88 & 4.78 \\ \text { Std. Deviation } & 0.57 & 0.71 & 0.57 & 0.77 & 0.79 & 0.35\end{array}$

*Result significant at 0.05 level

**Result significant at 0.01 level 
1

2

3

4

5

6
7

8

9

10

11

12

13

14

15

16

17

18

19

20

21

22

23

24

25

26

27

29

30

31

32

33

34

35

36

37

38

39

40

41

42

43

44

45

46

47

48

49

50

51

52

53

54

55

56

57

58

59

60

Figure 1. Map of study areas 
${ }_{\mathrm{i}}^{\mathrm{a}}$ broad wetland with an open area in its center: see http://eunis.eea.europa.eu/habitats/10154

1

2

4

5

6

7

8

9

10

11

12

13

14

15

16

17

18

19

20

21

22

23

24

25

26

27

28

29

34

35

36

37

38

39

40

41

42

43

44

45

46

47

48

49

50

51

52

53

54

55

56

57

58

59

60 


\section{Page 47 of 47}

1

2

3

4

5

6

7

8

9

10

11

12

13

14

15

16

17

18

19

20

21

22

23

24

25

26

27

28

29

30

31

32

33

34

35

36

37

38

39

40

41

42

43

44

45

46

47

48

49

50

51

52

53

54

55

56

57

58

59

60

(c) Metsähallitus 2016

(C) NLS of Finland 1/MML/16

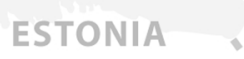

Figure 1. Map of study areas

$97 \times 150 \mathrm{~mm}(300 \times 300$ DPI $)$ 